\title{
THE GOLDEN AGE OF DETECTIVE FICTION: GENRE CONVENTIONS OF AGATHA CHRISTIE'S COSY MYSTERIES
}

\author{
Farman J. Ramazan \\ e-mail: farmanjawhar@yahoo.com,orcid.org/0000-0003-0319-2418
}

\section{Summary}

The article focuses on the investigation of detective fiction in general and detective stories in particular which in this research is understood as a narrative where the plot hinges on a crime that the characters investigate and attempt to solve. The research also deals with various genre types of detective stories, such as police-department procedurals, hardboiled, locked room mysteries, cosy mysteries. Special attention is paid to the genre development of detective stories from a historical perspective. It is worth underlining that the period between World War I and World War II (the 1920s and 1930s) is generally referred to as the Golden Age of Detective Fiction. The purpose of the study is to highlight the main plot elements of a cosy mystery, such as the protagonist, the antagonist, the setting, the crime event, and definite narrative mechanisms involved in a story.

Keywords: detective fiction, detective stories, Agatha Christie, cozy mysteries, elements of plot structure.

\section{DOI: https://doi.org/10.23856/4902}

\section{Introduction}

Today crime fiction is still extremely popular due to the works of such writers as: E.A. Poe, Sir A.C. Doyle, A. Christie, R. Chandler, D. Hammett, G. Simenon to name a few. There are many synonymic terms used to define crime fiction and especially the detective story subgenre. It is a well-known fact that detective fiction or detective story is one of the subgenres of crime fiction (Geherin, 1999) in which a detective - either professional, amateur or retired investigates a crime, often murder. The subject of that kind of story is the investigation aimed at detecting the perpetrator of a crime described at the beginning of the story. Most detective stories are written from the point of view of a detective about a definite crime, that's why they are also called "whodunnit" stories or crime stories (Babelyuk, 2019a, 2019b).

In this research a detective story is understood as a narrative which plot hinges on a crime that the characters investigate and attempt to solve. The precursor of this subgenre is Edgar Allan Poe, the author of the famous story "The Murders in the Rue Morgue". In this story, the protagonist-detective is investigating a crime and, as the plot is unfolding, he experiences great pleasure from the very process of looking for the evidence: His eyes were now hard and bright. And I understood that using his unusual reasoning power to find the answer to those bloody murders was giving Dupin (a detective) great pleasure! (Poe, 2012: 17). This statement can be, to our minds, the shortest definition of the literary essence of a detective story.

Among famous detective story writers, it is worth mentioning Agatha Christie, often called the Queen of Crime. Agatha Christie produced long series of books (stories, short stories, novels, plays) featuring her detectives Hercule Poirot and Miss Marple, amongst others, and usually including a complex puzzle for the reader to try to unravel. She and other authors from the Golden Age of Detective Fiction have created a legacy of detective novels based on gathering clues and 
solving crimes as if they were puzzles the reader can solve with the detective. In contemporary literature, this style has evolved into what now is called cosy mysteries. Among Agatha Christie the most popular novels we cannot but mention: "Murder on the Orient Express", "Death on The Nile", and "Ten Little Niggers". The purpose of the study is to highlight the main plot elements of cosy mysteries by Agatha Christie, such as the protagonist, the antagonist, the setting, the crime event and definite formal narrative mechanisms. Let's analyze deeper genre peculiarities of some cosy mysteries by Agatha Christie (Babelyuk, 2019a).

\section{Genre development of detective stories in historical perspective}

Detective stories are a relatively new type of stories, as they are dated back to the end of the 18th century and the beginning of the 19th century. At that time, they enjoyed enormous popularity in Europe and the USA. Among famous detective story writers, it is worth mentioning Agatha Christie, Sir A.C. Doyle, D. Hammett, G. Simenon, R. Chandler.

Crime fiction might be perceived as an umbrella term that adopts many values, from the early epoch of detective stories mostly about ratiocination (e.g. Arsène Lupine by Leblanc or Sherlock Holmes by Doyle), by the riddles of the Golden Age (Poirot or Miss Marple series by Christie, Lord Peter Wimsey by Sayer or American Ellery Queen), to private detectives of Hammett or hard-boiled of Chandler, professional police investigators which procedure for the thrillers (actions, pathology, forensics, etc.).

The period between World War I and World War II (the 1920s and 1930s) is generally referred to as the Golden Age of Detective Fiction. During this period, many popular writers emerged, including mostly British but also a notable subset of American and New Zealand writers. It is interesting to say, but female writers constituted a major part of notable Golden Age writers. Among them: Agatha Christie, Dorothy L Sayers, Josephine Tey, Margery Allingham, and Ngaio Marsh (a New Zealander) were particularly famous British female writers of this time. This can be explained by the fact that through the Roaring Twenties in all spheres of social life womenflappers enjoyed the new freedoms ushered in by the end of World War I and the dawn of a new era of prosperity, urbanism and consumerism. By the way, though the exact origin of the term "flapper" is unknown, it is assumed to have originated in Britain before World War I to describe gawky young teenage girls. Later, after the war, the word became a synonym of 1920s women who bobbed their hair above their ears, wore skirts that skimmed their knees, smoked cigarettes and drank alcohol while dancing in jazz clubs, always surrounded by admiring male suitors.

In the Golden Age of detective stories, an outsider - sometimes a salaried investigator or a police officer, but often a gifted amateur - investigates a murder committed in a closed environment by one of a limited number of suspects. Such scholars as Carole Kismaric and Marvi Heiferman underlined setting peculiarities of detective fiction of that period: "high-class amateur detectives sniffing out murderers lurking in rose gardens, down country lanes, and in picturesque villages" (Kismaric\&Heiferman, 1999). As a result, many conventions of the detective genre evolved at that time, as many writers tried their hands at that genre. Among them, we cannot but mention A. Christie.

During her lifetime, Agatha Christie wrote sixty-six detective novels and fourteen short story collections. According to the Guinness World Records (2018) her novel "And Then There Were None" remains one of the best-selling books of all time. At the same time, she is also the best-selling fiction writer of all time. The literary contribution of Agatha Christie is that she has created not one but two of the most famous detectives in literary history: Hercule Poirot and Miss Marple. As critics mention these detective characters remain highly influential to contemporary crime fiction writers (Koliasa, 2019a, 2019b). 


\section{Philosophic, social and genre assumptions of detective stories}

When we speak about not only the literary but also the philosophic and social essence of detective stories they are essentially about a crime and investigation but also about the law violation due to moral and legal crime, the infraction of social values. Besides, detective stories are overfilled with motives and ways of committing a crime, that's why there is a deep concern about characteristics, psychological motivations and details of life, which gives investigators definite clues and the possibility to departure from what is considered to be normal. In addition, crime and criminals are indicators of a particular cultural perception of legal behaviour. They might be a barometer of social values and morality reflecting or interrogating what is recorded as a crime. The reason why a particular action might be considered deviant gives us an insight into some ideologies or cultural peculiarities at a definite time in a given culture.

It is worth mentioning that each of the crime subgenres has its specific characteristic thus there are different challenges for the reader, e.g. the early mysteries or puzzles with their closed circle of threads often take place in a country house with diverse differences among social classes (A. Christie), creating a culturally specific description of importance (R. Chandler), there are registration or even misdirection of the reader (D. Hammett).

Taking into account the abovementioned plot peculiarities of detective stories one can distinguish the following types: police-department procedurals detective stories are focused on police work and often feature homicide investigators and other departments of a local police force; hardboiled detective stories usually describe dark setting and mood, are rather explicit, featuring a veteran detective who treats violent crimes matter-of-factly. Among hard-boiled fiction's authors such as R. Chandler (2001), the narration revolves around action, not thinking. That stories also evoke a very special setting, e.g. medium urban streets in America inhabited mostly by criminals, who are often involved in organized crime groups, speaking street slang, investigated by a private eye, and speaking in a casual, modern, laconic tone.

Thrillers detective stories emphasize suspenseful storytelling, often featuring chase scenes or murder sprees that the detective must stop before times runs out; locked-room detective stories feature crimes that, at the outset, appear impossible (for instance, a murder taking place in a seemingly locked room with no other way in or out); cosy mysteries detective stories have a lighter tone than traditional detectives, there are no explicit depictions of the murder. They are often set in a small town and focus on puzzle-solving rather than suspense.

\section{Interpreting plot elements of the cosy mysteries by Agatha Cristie}

It is said that the cosy mystery genre has its roots in early 20th century British mysteries (Agatha Christie and Dorothy L. Sayers) but took off in the late 20th century in an attempt to recreate that Golden Age of detective fiction, and as a response to the hardboiled crime fiction that became popular in the USA in the mid-20th century.

Agatha Christie established many of the elements which she continued to employ for fifty years: a country setting, a formulaic structure in which all is not what it seems, and a detective who keeps clues to himself, making a startling revelation of guilt and innocence in a final meeting of all the characters. Although the thought of as a conventional detective writer, she is credited with developing several new components of the mystery genre.

In "The Murder of Roger Ackroyd" (1926), Agatha Christie introduced a new twist to the mystery genre by making the narrator the murderer. In "The Murder on the Orient Express" (1934) all of the possible suspects turn out to be equally guilty. 
In "Hercule Poirot's Christmas" (1938), it is the investigating policeman who blurts out a confession in the penultimate chapter. No character can ever be safely exempted from suspicion and Agatha Christie, indeed, is adept at playing on and against the generically conditioned reflexes of even her most hardened readers.

In "Death on the Nile" (1937), for example, the solution to Linnet Doyle's murder is impossible to guess not only because the method of its commission is so original, but also because the killers are the two people whom our previous experience of Christie's writing would lead us to exclude as possibilities, the prime suspect and a clean-cut English gentleman.

In general, all the characters of cosy mysteries are more likeable in comparison to hardboiled detectives, and antagonists are not too darkly depicted or awful. More than that, the villain is often someone that the protagonist knows. The protagonist is an amateur sleuth who is quite often a woman.

Christie's favourite among her detectives was Ms Jane Marple, an elderly spinster who first appeared in Murder at the Vicarage, in 1930. In "Agatha Christie: First Lady of Crime" (Keating, 2021), Julian Symons (1983), a British crime writer, gave Christie's views of her two famous detectives: "Miss Marple, ... was more fun (than Poirot), and like many aunts and grandmothers was a splendid natural detective when it comes to observing human nature". In contrast to Poirot, a professional detective who attributes his successes to the use of his "little grey cells," Miss Marple is an amateur crime solver who often counts on intuition and nosiness. Believing that human nature is universal, she ferrets out the criminal by his resemblance to someone she has known in her native village of St. Mary Mead. She also stresses the importance of talking to people to find clues and she goes a little far on this view that she pays much attention to gossip. She is the archetype of the elderly lady detective (Pirkis\&Slung, 2020).1t is she who established a new method of detection: analogy.

In cosy mysteries by Agatha Christie, the protagonist might be on good terms with the police or investigating detective (she might even have a flirtation with them), but she usually solves the crime without too much of their help - or for whatever reason, the police might not be able to properly investigate the crime, leaving it entirely up to the protagonist.

In contrast, Christie's narratives are mobilized within a fairly strict framework of the "Golden Age of Detective Stories" convention. The setting is a cosy and closed environment that contains a limited number of characters and is disrupted by an act of unseen violence, The initial suspect is sometimes the second party to be murdered, which emphasizes both the ineptitude of the police and the importance of the assistance of either an amateur. (e.g. Miss Marple) or a semi-professional (e.g. Hercule Poirot) detective. Finally, and most importantly, the solution of the mystery marks a return to order and well being.

The settings of cosy mysteries play an important role in the analyzed detectives. From that time on that Agatha Christie made the secluded British manor or the charming village fan favourites for cosy settings, a cosy mystery can be set anywhere. From a small town in England to an Asian market or a deserted island. However, one thing that cosy mysteries generally have in common is a sense of community: the protagonist knows his/ her community, takes an active part in it, and knows a lot of the characters who live there.

As a female writer, Agatha Christie paid much attention to the description of characters' mental status and interpersonal relationships. Seldom did she turn to violence or power to attract readers. As a crime writer, she could not avoid touching upon the cruelty of crimes, the tragic ending of victims. This contributes to the very real feeling of evil and malevolence that is so marked a characteristic of this particular genre. And yet in Christie's book, the evil is not suffocating and uncleanly as many modern stories have it; it is not used as the focus of the novel to stimulate readers' senses. With Christie's detectives, the psychology of the criminal or the 
murderer became important. Important not only because it is made a fuss of, but also because it often provides a lead or even a clue to the murderer.

While interpreting the plot peculiarities of Agatha Christie cosy mysteries, the important thing is that the protagonist learns of a mystery, there are definite stakes, and plenty of unexpected twists. Such genre conventions and formal narrative mechanisms encourage the existence of subversions that disrupt the reader's expectations and sometimes generate a wrong direction through red herrings (misleading clues), interference, rhetorical manipulation and the use of cohesive devices to generate or obstruct false cohesion.

\section{Conclusion}

Having been neglected and refused by the academic circle for many years, systematic studies in the domain of the detective genre have rarely been tried before. The present author has attempted to demonstrate the importance of a systematic explication of the specifics of plot structure elements in Agatha Christie cosy mysteries. Based on an in-depth analysis, the present paper is expected to throw some light on genre conventions of the detective genre. Another major contribution of this study has been the refinement of an understanding of the attraction of Christie's works from the specifics of plot structure elements and character depiction, or, in other words, Christie's technique in attracting readers through stylistic peculiarities. Based on this tentative study, we may realize that the detective genre, as a branch of popular literature, may provide us with a broad research area in stylistics, literary critics and comparative literature studies.

\section{References}

1. Babelyuk, O. (2019a). Decoding Poetic Colouring of Detective Stories: Principles of Reading. In TRADITIONS AND INNOVATIONS IN TEACHING PHILOLOGICAL DISCIPLINES, 18-36. Liha-Pres.

2. Babelyuk, O. (2019b). Structural Peculiarities of Detective Stories. In VECTORS OF THE DEVELOPMENT OF PHILOLOGICAL SCIENCES AT THE MODERN STAGE, 21-38. Liha-Pres, $2019 b$.

3. Chandler, R. (2001). The Raymond Chandler Papers: Selected Letters and Non-Fiction, 199-1959. Harlow, England: Penguin Books.

4. Christie, A. (2011). Detectives and Young Adventurers: The Complete Short Stories. London, England: HarperCollins.

5. Christie, A. (2018). The mysterious affair at styles. Harper Collins.

6. Geherin, D. (1999). Detective story. The World Book Encyclopedia. Chicago, World Book Inc., 1999. 10. Heissenbuttel, H. (1983). The Detective Novel as Game. Most, Glenn W. \&. Stowe, William W.

11. Keating, H. R. F., ed. (2021). Agatha Christie: First Lady of Crime. Thorndike Press Large Print. 12. Kismaric, C. \& Marvin Heiferman. (1999). To the Rescue-Eight Artists in an Archive. New York, NY: American Jewish Joint Distribution Committee.

13. Koliasa, O. (2019a). Presentation of Images in Detective Stories. In TRADITIONS AND INNOVATIONS IN TEACHING PHILOLOGICAL DISCIPLINES, 142-59. Liha-Pres, 2019.

14. Koliasa, O. (2019b). Detective Stories: From Classic to Postmodern. Definition and History. In VECTORS OF THE DEVELOPMENT OF PHILOLOGICAL SCIENCES AT THE MODERN STAGE, 95-113. Liha-Pres, 2019.

15. Neimark, E. (1987). Neimark Adventures in Thinking. London, England: Thomson Learning. 16. Pirkis, C. L.\& M. Slung. (2020). Experiences of Loveday Brooke, Lady Detective. Mineola, NY: Dover Publications.

17. Poe, E. A. (2012). Tales of Mystery and Horror: Vol.Iii. Anstey, England: Ulverscroft. 